\title{
DE RHETORIBUS DE SUETÔNIO
}

\author{
Artur Costrino* \\ * Doutorando na \\ University of York em \\ Medieval Studies.
}

RESUMO: O artigo visa apresentar ao leitor uma tradução inédita em português da vida dos rétores (que é parte da obra De Grammaticis et Rhetoribus) de Suetônio. Como introdução, discute-se o lugar do gênero Vita em relação ao gênero Historia. Ainda há uma explanação sobre o "prefácio" da obra, o qual Suetônio divide em: história da declamação e praeexercitamina, de modo que o "prefácio", então, não se enquadra no gênero Vita.

PALAVRAS-CHAVE: biografia; gêneros; exercícios retóricos; declamação.

\section{THE RHETORIBUS OF SUETONIUS}

ABSTRACT: The article aims to provide the reader with an unprecedented Portuguese translation of the life of rhetoricians (which is part of the work De Grammaticis et Rhetoribus) of Suetonius. As an introduction, we discuss the place of genre Vita in relation to the genre Historia. There is still an explanation of the "Preface" of the work, which Suetonius divides into: history of declamation and praeexercitamina, so the "Preface," then, does not fit the genre Vita.

KEYWORDS: biography; genre; rhetorical exercises; declamation.

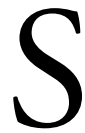

uetônio, autor da passagem do século I para o II da nossa era, escreveu, dentre muitas obras que não chegaram até nós, biografias ou, como eram chamadas pelos latinos, uitae. A obra traduzida aqui, De Rhetoribus, na verdade é a segunda parte de uma única obra, De Grammaticis et Rhetoribus, que, por sua vez, fazia parte de um projeto maior do autor de narrar as vidas dos homens 
ilustres de seu tempo. Suetônio escreveu a vida dos gramáticos e a vida dos rétores em conjunto, assim, unidas, essas obras circularam na Antiguidade e na Idade Média; assim também encontramos essas obras traduzidas neste mesmo volume. Suetônio não foi o primeiro a narrar vidas na Antiguidade e antes dele já havia um debate para posicionar o gênero ou subgênero uita entre as práticas letradas tanto romanas como gregas. Para um entendimento mais embasado do texto, vale a pena prestarmos atenção ao que diziam os comentadores antigos sobre o (sub)gênero da "biografia", ou melhor uita, e como podemos distinguilo dos demais subgêneros da historiografia.

\section{DistinÇÃO ENTRE OS GÊNEROS}

A historiografia antiga pode dividir-se em subgêneros distintos, tais como os anais, os comentários, a história universal, a monografia etc. Apesar das semelhanças, a vida ou biografia não se configura como um subgênero historiográfico, mas como um gênero confim, próximo a esse. Cornélio Nepo propõe uma distinção particular entre história e vida, assim:

O tebano Pelópidas é mais conhecido pelos historiadores do que pelo vulgo; hesito de que modo exporei suas virtudes, pois temo que, se começar a explicar as açôes (res explicare), parecerei não narrar a vida dele (uitam enarrare), mas escrever história (historiam scribere) (Cornélio Nepo. Pelópidas, I).

Assim também, Plutarco, contemporâneo de Suetônio e igualmente biógrafo, diz:

Escrevendo neste livro a vida (bíon) do rei Alexandre e a de César, por quem Pompeu foi derrotado, em vista da abundância das açôes implicadas, não diremos nada como preâmbulo, apenas suplicando ao leitor que não nos denigra por não relatarmos tudo que foi celebrado, nem abordamos cada coisa a fundo, abreviando a maioria dos fatos. É que não escrevemos histórias, mas vidas (oúte gàr historias gráphomen, allà bious) - e não é nas ações mais célebres, em absoluto, que está a demonstração de virtude (aretés) ou do vício (kakias), mas, muitas vezes, um breve 
feito, uma palavra, uma brincadeira dão ênfase ao caráter mais que os combates mortais, as maiores batalhas e os assédios de cidades. Portanto, como os pintores salientam as semelhanças a partir do rosto e das formas visíveis em que se manifesta o caráter, preocupando-se menos com as partes, assim também deve-se permitir-nos penetrar antes nos sinais da alma e, através disso, desenhar a vida de cada um, deixando as grandezas e os combates (kaì dià toúton eidopoieîn tòn hekástou bion, eásantas hetérois tà megéthe kaì toùs agónas) (Plutarco. Vida de Alexandre 1, 1-3, trad. Jacyntho Lins Brandão).

Notemos, pois, a clara distinção entre o "narrar uma vida" e "explicar açôes" ou "escrever história" presente tanto no pequeno excerto de Nepo, quanto na passagem de Plutarco, nas quais se distingue justamente a "unidade" que cada obra possui. Assim, se para a história é próprio o "explicar grandes ações”, para a vida, ao contrário, é próprio o "narrar uma vida", expor um "caráter" através da descriçãoo de pequenas ações empreendidas pela pessoa a ser biografada. Aristóteles, no "sexto capítulo" da Poética, alude a uma distinção entre a unidade de ação e a unidade de caráter:

Sem ação não poderia haver tragédia, mas poderia havê-la sem caracteres. As tragédias da maior parte dos modernos não têm caracteres, e, em geral, há muitos poetas desta espécie. Também entre os pintores, assim é Zêuxis comparado com Polignoto, porque Polignoto é excelente pintor de caracteres e a pintura de Zêuxis não apresenta caráter nenhum. (Aristóteles, Poética, cap. 6; par. 33, trad. Eudoro de Sousa).

A observação de Aristóteles, destinada à tragédia, pode ser tomada de modo a abarcar narrativas poéticas apenas e não "históricas". Todavia, assim como Aristóteles prescreve que a unidade de uma obra poética deve ser a ação, os poetas poderiam não seguir tal conselho, pois houve poemas em que a unidade fora não a ação (como a Ilíada), mas o caráter (como a Teseida ou a Heracleida); ou seja, a prática poética diferenciavase das preferências aristotélicas. O mesmo vale para a história, pois, para Aristóteles, a unidade desse tipo de obra é a de tempo. Porém, o único subgênero da história que tem como unidade o tempo são os anais. Logo, para Aristóteles, tal 
subgênero seria o único a ser admitido como História. Contudo, assim como as práticas poéticas, as práticas historiográficas também são diferentes das preferências de Aristóteles, pois os historiadores nem sempre usaram da unidade de tempo prescrita pelo Estagirita para a História, mas, ao contrário, os autores de História valeram-se da unidade prescrita para a poesia, ou seja, usaram da unidade de ação, enquanto os autores de biografias usaram a unidade de caráter, e nenhum deles usou a unidade de tempo. É importante notarmos que Aristóteles, no trecho em questão, cita dois pintores, um pintor de caracteres (Polignoto) e outro, de açōes (Zêuxis). Ora, assim também Plutarco escreve que a obra dele é como aquela dos pintores que "salientam as semelhanças a partir do rosto e das formas visíveis em que se manifesta o caráter, preocupando-se menos com as partes", de modo que ratifica a analogia aristotélica entre pintura e escrita e se inscreve junto a Polignoto como pintor de caracteres.

Ainda é necessário assinalar outra característica comum a ambos os gêneros. Plutarco escreve que "desenhar a vida de cada um" se faz por meio da "demonstração de virtude ou de vício"; ora, virtude e vício são justamente as palavras pelas quais se define o discurso epidítico da retórica, o qual, justamente, tem como finalidade o elogio da virtude e o vitupério do vício; portanto, Plutarco estaria a assinalar o caráter epidítico do gênero biográfico.

Enfim, Políbio, que tanto praticou a história quanto a "vida", diz:

Se eu não tivesse escrito sobre Filopêmen uma obra à parte, onde revelo quem era ele e de que família provinha, e a natureza de sua formação quando jovem, ser-me-ia necessário expor todos esses aspectos agora. Mas, considerando que já lhe dediquei anteriormente uma obra em três livros (...), onde exponho a sua formação desde menino e enumero seus feitos mais famosos, é óbvio que na presente narrativa o procedimento adequado é omitir detalhes relativos à sua formação inicial e às ambições de sua juventude, e em vez disso acrescentar detalhes à exposição resumida que fiz nessa obra à parte acerca de seus feitos na maturidade, pois assim o caráter próprio a cada obra poderá ser preservado. De fato, assim como o tratamento anterior, escrito em forma encomiástica, impunha uma exposição sumária e um 
tanto exagerada de seus feitos, a presente História, onde são distribuídos imparcialmente louvores e censuras, impõe um relato rigorosamente verídico, no qual é apresentado o fundamento de cada louvor e de cada censura, acompanhado em cada caso dos comentários pertinentes (Políbio. Histórias X, 21, trad. Mário da Gama Kury)

Neste trecho, mais uma vez, podemos observar as diferenças entre os gêneros biográfico e historiográfico. Políbio nos informa que escrevera uma obra a respeito somente de Filopêmen, que continha informaçóes como a família, a formação, feitos de juventude do biografado; em contrapartida, na obra historiográfica que está a escrever, o autor omite isso que já narrara, mas "acrescenta detalhes à exposição resumida" de tal modo que se mantenha o caráter próprio de cada obra, ou seja, aquilo que cada obra deve conter. O autor vai além ao reportar que a obra "biográfica" tinha forma "encomiástica" onde eram descritos os feitos do biografado de modo breve e exagerado, enquanto na história zela-se pela "credibilidade", ao tentar atingir a maior imparcialidade possível, não só por narrar, mas, principalmente, por detalhar cada louvor e cada vitupério contidos na obra.

Podemos notar que, do mesmo modo que Plutarco, Políbio indica que o gênero biográfico se filia ao gênero epidítico da retórica, de modo que sua obra biográfica fora escrita de modo a exagerar os feitos do biografado. Todavia, também a história faz parte do gênero epíditico, pois, segundo Políbio, a história é o gênero "onde são distribuídos imparcialmente louvores e censuras", que justamente são os modos do gênero demonstrativo da retórica.

Assim, podemos agora resumir em que diferem e em que se assemelham a vida e a história. Parece-nos, pois, por esses testemunhos antigos de biógrafos e historiadores e também de filósofos, que ambos os gêneros se inscrevem no gênero laudatório da retórica, embora a história procure demonstrar imparcialidade, e diferem pela "unidade", uma vez que a história possui uma unidade de ação, e a vida, unidade de caráter. 


\section{ANÁlise do PREFÁCIO}

Passemos agora ao exame do prefácio do De rhetoribus. O que primeiro notamos é que não há uma discussão a respeito do gênero biográfico ou, como acontece no prefácio do livro de Cornélio Nepo, uma explicação dos diferentes costumes de outros povos, que alerte o leitor sobre as biografias dos líderes e costumes desses. Na verdade, o autor começa seu texto por nos explicar os inícios da retórica em Roma, como foi aceita com dificuldade e, por duas vezes, legalmente banida. Para comprovar o banimento, aliás, Suetônio relata dois documentos oficiais, a saber: um senatoconsulto e um édito dos censores. Depois, Suetônio mostra como a retórica adquiriu seu lugar de destaque na vida romana e, para isso, dá exemplos de homens ilustres, generais e príncipes, que se dedicaram a ela.

Ora, nessa primeira parte do prefácio, não é escrita uma única palavra a respeito do gênero ao contrário do que se vê de obras similares; de fato, mais do que um prefácio, Suetônio parece escrever uma "introdução", pois em uma obra que se presta a narrar a vida (enarrare uitam), o autor começa por explicar a matéria (explicare rem), e não propriamente a matéria de que tratará, isto é, as vidas dos rétores, mas a matéria da qual trataram aqueles dos quais Suetônio tratará, isto é, da introdução, desenvolvimento e aperfeiçoamento do ensino da retórica em Roma. Porém explicar como a retórica adentrou em Roma e lá se desenvolveu não é matéria própria de um biógrafo. Além disso, Suetônio dedica um parágrafo inteiro a exercícios retóricos que em grego recebera o nome de progymnásmata, ou seja, exercícios preparatórios. Tal parágrafo deve ser visto com certo estranhamento, pois, se a discussão anterior, sobre a inserção da retórica em Roma, já não seria, a princípio, matéria para uma "vida", mas sim para uma "história", menos então uma exposição dos exercícios aplicados pelos professores de retórica. Pois, segundo Quintiliano e o próprio Suetônio, em Roma, os responsáveis por aplicar tais exercícios não eram os rétores, mas sim os gramáticos. 
Mas a maneira de ensinar nem sempre foi uma para todos nem única a mesma para cada um, pois que cada qual exercitou seus discípulos de modo vário. Pois se acostumaram a expor tanto aquilo que foi dito de modo ilustre, quanto os apólogos, de uma e outra maneira por meio de todas as figuras, e a explicar as narrações não só com brevidade e precisão, mas ainda também com mais vigor e mais riqueza, entrementes, a traduzir os escritos dos gregos e a elogiar ou vituperar homens ilustres; a mostrar também que algumas coisas instituídas ao uso da vida comum são, por um lado, úteis e necessárias, por outro lado, perniciosas e supérfluas; freqüentemente a confirmar ou tirar a credibilidade de umas histórias, o qual gênero de tese os gregos chamam tanto de anaskeuai quanto de kataskeuai. Até que estes exercícios se esvaeceram imperceptivelmente e se chegou à controvérsia. (Suetônio. Dos rétores. 25, 8).

Suetônio expõe o que consta em cada exercício, sem, muitas vezes, explicitar-lhes os nomes técnicos que possuem; se, porém, nos basearmos nos nomes latinos mencionados por Quintiliano, podemos identificar: $1^{\circ}$ usus, sententia: "Pois se acostumaram tanto a expor aquilo que foi dito de modo ilustre (...)"; 2o fabula: “(...) apólogos (...)"; $3^{\circ}$ narratio: "explicar as narrações (...)"; 4 o "conuerto": "traduzir os escritos dos gregos"; 50: laus ac uituperatio: "elogiar ou vituperar homens ilustres"; 60 legis latio/positio: "mostrar também que algumas coisas instituídas ao uso da vida comum são, por um lado, úteis e necessárias (...) por outro lado, perniciosas e supérfluas"; $7^{\circ}$ : confirmatio et refutatio: "confirmar ou tirar a credibilidade de umas histórias, o qual gênero de tese os gregos chamam tanto de anaskeuai quanto de kataskeuai."

De todos os manuais sobre progymnásmata escritos, o mais antigo que chegou até nós foi o de Élio Teão de Alexandria, que viveu durante a primeira metade do século I da nossa era; todos os demais manuais de progymnásmata são posteriores ao século II, e, portanto, posteriores a Suetônio. Esses manuais expunham os exercícios não em uma ordem aleatória, mas em ordem de dificuldade crescente. Do manual de Teão, em particular, podemos assinalar que: $1^{\circ}$ é o único que não distingue chria de gnóme, ou, em latim, usus de sententia; $2^{\circ}$ é o único que começa com a chria (usus/sententia), em vez de começar pelo mythos 
(fabula). Ora, Suetônio parece, justamente, não distinguir usus de sententia, e começa, em sua enumeração, também pelo usus/sententia, assim como Teão. Poderíamos apontar também que o restante da ordem da exposição de Suetônio segue de perto a ordem de Teão, embora não enumere todos os exercícios que este discute e, além disso, exponha um exercício que não consta nem em Teão, nem em nenhum outro: o exercício da tradução.

Isso tudo nos dá algumas indicações de quais tenham sido as fontes de Suetônio para escrever essa parte do prefácio: provavelmente o texto de Teão ou algum texto do qual esse dependa ou que dependa desse, sobretudo porque Suetônio nos informa que em Roma tais exercícios eram ministrados pelos gramáticos, e não pelos rétores, ao passo que em Atenas eram justamente os rétores que os aplicavam. Em suma, a fonte de Suetônio teria sido, aqui, não um outro biógrafo ou mesmo um historiador, mas sim um manual de exercícios preliminares, muito provavelmente grego. De resto, Suetônio ainda relata o surgimento das controuersiae e dá exemplos de duas delas.

Assim, podemos concluir que as características do gênero biográfico, a saber: a unidade de caráter e o elogio e o vitupério, são ausentes do prefacio de Suetônio.

\section{DOS RÉTORES}

XXV - 1 A retórica também foi recebida entre nós do mesmo modo que a gramática, tardiamente e ainda com um pouco mais de dificuldade, com efeito, essa consta, não raro, até ter sido proibida de ser exercida. Para que isso a ninguém seja duvidoso, acrescentarei um antigo senatoconsulto, e também um édito dos censores: "no consulado 1. 161a.C. de C. Fânio Estrabão e M. Valério Messala, ${ }^{1}$ o pretor M. Pompônio consultou o senado. Uma vez que a pauta foi feita a respeito dos filósofos e dos rétores, sobre este assunto assim decidiram que o pretor M. Pompônio repreendesse e cuidasse de que do ponto de vista do bem da república e da sua fidelidade lhe parecesse que não devessem estar em Roma”. 
Sobre os mesmos, transcorrido um tempo, os censores Cn. Domício Aenobarbo e L. Licínio Crasso assim proclamaram este édito: "Foi relatado a nós haver homens que instituíram um novo gênero de disciplina, aos quais a juventude se reuniria em uma escola: estes se autodenominaram rétores Latinos. Lá os jovens ainda rapazinhos passam dias inteiros desocupados. Os nossos antepassados instituíram o que gostariam que os seus descendentes aprendessem e a quais escolas freqüentassem, estas inovações, que se fazem contra o hábito e o costume dos antepassados, nem agradam e nem parecem corretas; por isso, tanto para estes que possuem estas escolas, quanto para aqueles que se acostumaram a ir para lá, parece que o que se deve fazer é anunciar a nossa sentença: a nós não agradam".

2 Paulatinamente, a própria retórica mostrou-se útil e honesta, e muitos a procuraram tanto por causa de defesa quanto de glória. 3 Cícero até a pretura declamou continuamente ainda em grego, em latim, de certo, também até mais velho, e seguramente com os cônsules Hírcio e Pansa, aos quais ele chamava de 'discípulos e grandes pretextados'. 4 Certos historiadores contaram que Cn. Pompeu, sob a própria guerra civil, para que mais facilmente contradissesse o jovem muito desembaraçado C. Curiāo, que defendia a causa de César, voltou ao hábito de declamar; 5 que M. Antônio, assim como Augusto, não se omitiram nem mesmo durante a guerra Mutinense. 6 O César Nero declamou no primeiro ano de império, também em público, duas vezes antes. 7 Além disso, a maior parte dos oradores editou também as declamaçôes. Por isso, incutido nos homens um grande interesse, também uma grande abundância de professores e de doutos jorrou, e a tal ponto floresceu, que não poucos teriam avançado da mais ínfima fortuna à ordem senatorial e às sumas honras.

8 Mas a maneira de ensinar nem sempre foi uma para todos nem única a mesma para cada um, pois que cada qual exercitou seus discípulos de modo vário. Pois se acostumaram tanto a expor aquilo que foi dito de modo ilustre, quanto os apólogos, de uma e outra maneira por meio de todas as figuras, e a explicar as narrações não só com brevidade e precisão, mas ainda também com mais 
3. Essa bulla era também uma marca da condição de liberdade de quem a portava.

4. Essa era a vestimenta de uma jovem livre.

5. Essa epístola não chegou até nós dentro da correspondência de

Cícero; este é o único fragmento que temos dela. vigor e mais riqueza, entrementes, a traduzir os escritos dos gregos e a elogiar ou vituperar homens ilustres; a mostrar também que algumas coisas instituídas ao uso da vida comum são, por um lado, úteis e necessárias, por outro lado, perniciosas e supérfluas; freqüentemente a confirmar ou tirar a credibilidade de umas histórias, o qual gênero de tese os gregos chamam tanto de anaskeuai quanto de kataskeuai. Até que estes exercícios se esvaeceram imperceptivelmente e se chegou à controvérsia.

9 As antigas controvérsias eram extraídas ou das histórias, assim como certamente não poucas até hoje, ou da verdade e das coisas, se talvez por acaso algo recente tivesse ocorrido. Deste modo costumavam ser apresentadas com a adição dos nomes dos lugares. E assim, de certo, coligidas e editadas se apresentam as controvérsias, dentre as quais não terá sido inoportuno referir a uma e outra, à guisa de exemplo, palavra por palavra: "Como durante o tempo estivo adolescentes citadinos tivessem chegado a Óstia, depois de terem entrado na praia, se aproximaram aos pescadores que puxavam com a rede e estabeleceram quanto vale cada lance de rede; pagaram o dinheiro; Por muito tempo esperaram, até que as redes fossem puxadas. Finalmente puxadas para fora, não havia peixe dentro, mas uma alcofa de ouro fechada. Então os compradores dizem ser seu o lance, os pescadores, ser seu." "Como um comerciante tirasse da nau uma grei de escravos em Brundúsio, porque temia os aduaneiros, colocou em um menino formoso e precioso uma bula ${ }^{3}$ e uma toga pretexta. ${ }^{4}$ Facilmente a falácia ocultou. Chegou-se a Roma, o caso foi descoberto, o menino é requerido à liberdade, porque teria sido libertado pela vontade do dono."

Outrora, porém, os gregos chamavam estas também pelo nome de syntasis, logo controvérsias, certamente, mas ou forjadas ou judiciais. 10 Outros ilustres professores, dos quais também alguma memória subsista, serão descobertos não ao acaso; essa memória acerca desses referirei.

XXVI - 1 L. Plócio Galo. Sobre esse, Cícero, na epístola ${ }^{5}$ a M. Titínio, assim se refere: "certamente tenho na memória, em nossa meninice, que um certo Plócio foi o primeiro a começar a ensinar em Latim. Como junto a este se fizesse um assédio, porque homens estudiosíssimos se 
exercitassem junto a ele, lamentava que a mim não fosse lícito fazer o mesmo. Porém eu era detido pela autoridade dos mais doutos dos homens, que julgavam que os engenhos pudessem alimentar-se melhor com os exercícios gregos".

2 M. Célio, no discurso que fez em sua defesa $<$ no processo $>$ de violência, declara que esse mesmo - pois viveu por muitíssimo tempo - "ditou a ação a Atratino, seu acusador", e subtraído o nome, o chama de "retor que come pão negro", escarnecendo-o como "inchado", "fraco" e "sujo".

XXVII - 1 L. Voltacílio Piluto, diz-se, foi escravo e ainda porteiro preso em cadeias, de acordo com o antigo costume, até que libertado por causa do engenho e do estudo das letras, ajudou o seu patrono durante uma acusação. 2 Daí após ter sido professor de retórica, ensinou Cn. Pompeu, o Grande, e expôs as gestas do pai deste, e não menos do próprio, em muitos livros; "o primeiro de todos os libertos", como opina Cornélio Nepo, "que começou a escrever a história, habituada naquele tempo a ser escrita por ninguém menos que os mais honestos".

XXVIII - 1 M. Epídio, acusado de caluniar, abriu uma escola de discurso e ensinou entre outros Marco Antônio e Augusto; outrora para estes, adversários entre si, Canúcio, porque na administração da república seguisse mormente o partido do consular Isaurício, respondeu: "prefere ser discípulo de Isaurício a do caluniador Epídio". 2 Este Epídio anunciava-se descendente de C. Epídio Nucerino, que disseram que outrora foi jogado na fonte do rio Sarno e não teria reaparecido imediatamente, um pouco depois emergiu com chifres dourados e foi contado no número dos deuses.

XXIX - 1 Sexto Clódio, da Sicília, professor de eloqüência em latim e também em grego, mordaz e de má vista, dizia ter esmigalhado os dois olhos na amizade de $\mathrm{M}$. Antônio, o triúnviro. Disse que a esposa do mesmo, Fúlvia, que tinha uma das bochechas mais inflada, afiava a ponta do estilo, e nem assim ele foi por isso mais ou menos grato a Antônio. 2 Dele, logo cônsul, recebeu também um presente, como a ele Cícero objetas nas Filípicas: "Admites um mestre por causa do joguete, rétor pelo teu voto e dos teus companheiros de bebida, para o qual consentiste que dissesse contra ti o que desejasse, de todo, um homem acre, 
6. Para maiores detalhes a respeito dessa história ver Sêneca, o rétor. Controuersiae 7, Praefatio, 7. mas é matéria fácil dizer ditos oportunos contra ti e contra os teus. Mas quão grande foi o pagamento dado ao rétor! Escutai, escutai, Padres Conscritos, e conhecei as chagas da república: duas mil geiras do campo Leontino assinaste ao rétor Sex. Clódio, e certamente livre de impostos, de tal modo que aprendesses a saber nada com tamanho pagamento."

XXX - 1 C. Albúcio Silo, o novariense, como exercesse a edilidade na pátria, como acaso falasse o direito, foi arrastado pelos pés do tribunal por aqueles contra os quais se pronunciava. 2 Isso suportando indignamente, instantaneamente marchou até a porta e de lá até Roma, e, recebido no grupo do orador Planco, para o qual era praxe, quando ia declamar, primeiro chamar alguém que discursasse antes, aceitou esta participação, e de tal modo a desempenhou que impôs o silêncio a Planco, que não ousava expor-se à comparação.

3 Mas famoso por isso, inaugurou auditórios; habituado, proposta uma controvérsia, a começar sentado, e, impelido em fim pelo calor, a levantar e perorar, a declamar então por variados gêneros: ora de modo esplêndido e adornado, às vezes, para que em nenhuma parte fosse reconhecido como estudado, de modo sujo e entrecortado, mas tão somente com palavras não triviais. 4 Atuou também em causas, porém meio raramente, na medida em que busca a de maior importância, e em nenhuma busca lugar outro que o de perorar.

5 Posteriormente renunciou ao fórum em parte por pudor, em parte por medo: pois quando em um certo litígio afrontava alguém qual ímpio para com os pais, com um adversário centunviral, assim teria apresentado como por figura o juramento: "jura pelas cinzas do teu pai e da tua mãe que jazem insepultos", e outras coisas neste modo, o outro aceitando a condição e sem o repúdio dos juízes, concluiu o negócio não sem sua grande desgraça. ${ }^{6} 6 \mathrm{Em}$ seguida, defendendo um réu no processo de assassinato em Mediolano, perante o pró-cônsul L. Pisão, como os lictores coibissem as desmedidas vozes dos que louvavam, e de tal modo se tivesse exaltado que, deplorado o estado da Itália, como se outra vez fosse reduzida a forma de província, invocasse ainda por cima M. Bruto, cuja estátua estava à 
vista, autor e defensor das leis e da liberdade, quase pagou as penas.

7 Já então mais velho, voltou para Novária por causa de um tumor, e convocado o povo, apresentadas, longamente e à maneira de contendor, as causas pelas quais estivesse destinado a morrer, absteve-se de comer.

\section{REFERÊNCIAS BIBLIOGRÁFICAS}

\section{FONTES:}

ARISTÓTELES. Poética. Trad., intro. e comentários de Eudoro de Souza. Lisboa: Imprensa Nacional - Casa da Moeda, 1994.

Retórica. Intro. M.A. Júnior. Trad. M.A. Júnior, P.F. Alberto, A. N. Pena. Lisboa: Imprensa Nacional - Casa da Moeda, 1998.

CORNÉLIUS NEPOS. Ouvres. Texte établi et traduit par Anne-Marie Guillemin. Paris : Les Belles Lettres, 1923.

POLÍBIO. História. Trad. Mário da Gama Kury. Brasília : Editora da Universidade de Brasília, 1985.

SUÉTONE. Grammairiens et Rheteurs. Texte établi et traduit par Marie-Claude Vacher. Paris: Société d'Éditions "Les Belles Lettres", 1993.

SUETONIUS. De grammaticis et rhetoribus. Giorgio Brugnoli. Lipsae: Teubner, 1963. V. I, p.27-37.

With an English translation by J.C. Rolfe in two volumes. London: The Loeb Classical Library, 1979. V. I-II. TEÓN/HERMÓGENES/AFTÔNIO. Ejercicios de retórica. Introducción, traduccioón y notas de M. ${ }^{a}$ Dolores Reche Martinez. Madri: Editorial Gredos, 1991.

II. EsTUDOS

AMBROSIO, Renato. De rationibus exordiendi: função $e$ elaboração dos exórdios de Cornélio Nepos e Salústio Crispo. São Paulo: Associação Editorial Humanitas/Fapesp, 2005. 
AILlOUD, Henry. Suétone: Vies des Douze Césars. Paris: Société d'Éditions "Les Belles Lettres", 1954. Tomo I.

ATKINS, J.W.H. Literary Criticism in Antiquity. London: Methuen \& Co. Ltd, 1952. V. II.

CLARK, Donald Lemen. Rhetoric in Greco-Roman Education. Nem York: Columbia University Press, 1957.

INTRODUCTION in SUÉTONE. Grammairiens et Rheteurs. Texte établi et traduit par Marie-Claude Vacher. Paris: Société d'Éditions "Les Belles Lettres", 1993. p. VII - LXXXVII.

KENNEDY, George. The Art of Rhetoric in the Roman World. New Jersey: Princeton University Press, 1972.

MACE, Alcide. Essay sur Suetone. Paris: Ancienne librarie Thorin et Fils, 1900.

Enviado em janeiro de 2014 Aprovado em abril de 2014. 